\title{
Hoe verandert de intrapsychische architectuur?
}

- In dit artikel wordt een theorie ontwikkeld over het object van de psychotherapie, de intrapsychische architectuur, en over de wijze waarop dit door middel van openleggende psychotherapie kan worden beïnvloed. Dit gebeurt tegen de achtergrond van de toenemende assertiviteit van onderzoekers in de psychotherapie die menen dat de clinici vooral 'evidence based' behoren te werken. De essentiële ingrediënten die een psychotherapeutisch veranderingsproces kunnen kenmerken, te weten primaire emoties, hechting, cognitieve functies en bewustzijn, worden in samenhang geanalyseerd. Aan de hand van een casus wordt een en ander verder geillustreerd.

\section{De clinicus en de technicus}

Gedurende de afgelopen decennia is in menig empirische studie de effectiviteit van een uitgebreid scala aan psychotherapeutische interventies tegen het licht gehouden, met een overheersend positief resultaat. Snyder en Ingram concluderen op basis van een overzicht van het gehele vakgebied: 'the effects for psychotherapy appear to be as robust as those for educational interventions or medical procedures' (Snyder \& Ingram, 200o, p. 716). Zeker psychologen vallen op door hun gedrevenheid te bewijzen dat hun psychotherapeutische interventies empirisch kunnen worden ondersteund. En dit lijkt

PROF. DR. J.J.L. DERKSEN is hoogleraar klinische psychologie. Hij is werkzaam aan de Radboud Universiteit te Nijmegen en de Vrije Universiteit van Brussel. Daarnaast is hij al 30 jaar werkzaam in de eerstelijns- en psychotherapiepraktijk Derksen \& Klein Herenbrink te Bemmel. Hij heeft een psychoanalytische en cognitief-gedragstherapeutische opleiding. Correspondentie: jjlderksen@planet.nl 
niet te stoppen; in de vakliteratuur worden we nog bij voortduring getrakteerd op vergelijkingen in effect tussen interventies afkomstig uit verschillende psychotherapeutische modellen toegepast op uiteenlopende groepen cliënten.

Vertegenwoordigers van het zogenaamde scientist-practitioner model streven ernaar de kloof die zij observeren tussen onderzoek en praktijk te overbruggen door de onderzoeker en de clinicus in één persoon te verenigen; de (geregistreerde) klinisch psycholoog is hier bij uitstek een voorbeeld van. Een andere variant van hetzelfde thema is de overtuiging dat psychotherapeuten vooral en wellicht uitsluitend dienen toe te passen wat de onderzoekers hebben ontdekt. Men neemt daarbij vaak een voorbeeld aan de natuurwetenschappen: de ingenieurs werken met de ingrediënten die de fysici hen aanleveren. De moderne over-assertieve onderzoekers bedienen zich al weer enige tijd van het volgende jargon: evidence-based treatment (EBT) en evidence-based practice (EBP). EBT verwijst naar interventies en technieken die bewezen hebben therapeutische verandering te produceren in gecontroleerde studies. EBP is een bredere term die verwijst naar de klinische praktijk waarbij interventies en klinische expertise worden gedomineerd door informatie afkomstig uit onderzoek (Kazdin, 2008). Vanuit de onderzoekers in de klinische psychologie wordt een sterke druk uitgeoefend op de practici om in plaats van clinici technici te worden (Millon, Boice \& Sinsabaugh, 2008). Psychodiagnostiek en indicatiestelling zijn teruggebracht tot DSM-classificatie en het uitzoeken van een bijpassend protocol en het consequent toepassen daarvan. Kleine aanpassingen aan de individuele cliënt zijn toegestaan. Deze onderzoekers beroepen zich op studies die aangeven dat het toepassen van een empirisch gesteund protocol de beste keuze is en dat indicatiestelling een overbodige en tijdrovende zaak is; er is tenslotte nooit van bewezen dat het nut heeft. Het over-assertieve gedrag van veel onderzoekers en cognitiefgedragstherapeuten (tussen deze groepen bestaat veel overlap) is nadelig voor de saamhorigheid in het veld. Deze lieden zeggen meer of minder expliciet dat generaties psychotherapeuten die openleggende psychotherapie beoefenen vanuit cliëntgerichte, psychoanalytische, psychodynamische, systemische en andere oriënteringen geen bestaansrecht hebben. Het management van veel GGZ-instellingen omarmt het nieuwe jargon (EBT, EBP) met kritiekloos enthousiasme, de ervaren clinici worden in het nauw gedreven. Behalve animositeit in eigen kring bewerkstelligen de onderzoekers, mede hierdoor, een negatieve houding ten opzichte van deze openleggende klinische tradities bij beleidsmakers en verzekeraars. Dit type opstelling heeft geen positieve invloed op het veld of op de ontwikkeling van de discipline.

De onderzoekspraktijk in de psychotherapie is structureel en conceptueel heel anders georganiseerd dan de psychotherapeutische praktijk en bevindt zich daarmee ook op een geheel ander niveau. Het jargon in de onderzoekspraktijk illustreert dit: statistische significantie, randomized controlled trials, randomized clinical trials, operationele definities, kwantificering van relaties, precisie in evaluatie, het protocol volgen, placebo comparisons, component control designs, steekproefgrootte, effect sizes, statistical power, post hoc power analysis, DSM-diagnoses, etc. In tegenstelling tot de klinische praktijk vindt de on- 
derzoekspraktijk in een sterk gecontroleerde omgeving plaats; in de onderzoekspraktijk bepaalt een standaardafwijking het verschil op een klachtenvragenlijst, waarbij het gemiddelde van een groep cliënten de succesvolheid van een interventie uitdrukt. Doorgaans verdwijnen de individuen in de groepsgetallen zodat de individuele realiteit (de één verbetert een beetje, de ander iets meer, een ander blijft gelijk, etc.) wordt verduisterd.

In de klinische praktijk staat een uniek individu centraal dat hulp vraagt en klachten presenteert die in de tweede of derde zitting vaak blijken te verwijzen naar een algemeen probleem in het leven, naar een dieperliggende zwakke identiteit, naar verstoorde wensen die betrekking hebben op intieme relaties. Een DSM-diagnose is hier een beperkte classificatie die in een ongecontroleerde context snel aan betekenis verliest en over het behandelingsverloop weinig of niets voorspelt. In de klinische praktijk kunnen klachten verminderen terwijl problemen, die psychotherapeutische aandacht nodig hebben, blijven bestaan. In de woorden van de eerder aangehaalde Snyder en Ingram: 'One principal weakness of the DSM manual is that it used to label a person who may need or want help to change psychologically, but it does not have much to do with the actual interventions that this person will receive' (Snyder \& Ingram, 200o, p. 713). Het observatievermogen van de technicus (de jonge generaties psychologen en psychotherapeuten) is door de academische opleiding van het laatste decennium anders gevormd dan dat van de (vroeger opgeleide) clinicus. Waar de technicus doorgaans een cliënt ziet met een klacht die strak in kaart wordt gebracht en zeer gestructureerd wordt behandeld, ziet de clinicus vaak een individu met een probleem in diens leven waaraan hij of zij op dat moment geen woorden kan geven. Dit probleem wordt door de technicus vertaald in een etiket dat alleen de buitenkant ordent en verbonden wordt met een standaardprotocol dat de ogen sluit voor de weggedrukte belevingscontext en voor dieperliggende verlangens. Een paniekstoornis zonder agorafobie kan voor de clinicus tijdens de tweede, zo min mogelijke gecontroleerde, zitting een paniekreactie blijken te zijn op een verhulde wens van de patiënt om dood te zijn en daarmee verlost te worden van een belastend leven. Wat zich in de classificatie en in de onderzoekspraktijk als angst voor de dood presenteert, toont zich in de psychotherapeutische praktijk niet zelden als een verlangen naar de dood. Eenzelfde type verlangen naar de dood kan zich voor het sensitief luisterend oor van de diagnosticus in samenhang met een ernstig depressief toestandsbeeld ontpoppen, symptomen van een ernstige depressie blijken te verwijzen naar een weggedrukt probleem in de intieme relatie en in de beleving van seksualiteit.

In de klinische praktijk is de psychotherapeut vaak bezig mensen te helpen met hun leven te leren omgaan, in de onderzoekspraktijk worden doorgaans symptomen en stoornissen beïnvloed. Veel valide en betrouwbare metingen in de onderzoekspraktijk zijn arbitrair in de klinische praktijk (Blanton \& Jaccard, 2006; Kazdin, 2008). In plaats van controle in de onderzoekspraktijk staat in de klinische praktijk flexibiliteit centraal voor de clinicus en openleggend psychotherapeut. In plaats van Descartes 'cogito ergo sum' (ik denk, dus ik ben) wordt in de klinische praktijk deze dwingende ratio los 
gelaten en getransformeerd naar iets dat ik benoem als 'cognito ergo non sum' (ik denk, dus ik ben niet). Om het in termen van de vermaarde Franse psychoanalyticus Jacques Lacan (1971) te zeggen, de 'parole vide' van de classificatie wordt getransformeerd naar de 'parole pleine' van de klinische diagnostiek. Het inhoudsvolle spreken komt pas tot stand in het contact tussen twee unieke mensen. In de psychotherapeutische context gebeuren bij voortduring onverwachte dingen; de patiënt kan zich op allerlei momenten geheel anders tonen dan de DSM-classificaties en de daarop voortbordurende diagnostiek voor mogelijk hadden gehouden. De flexibele psychotherapeut kan hiermee creatief omgaan en wisselt bijvoorbeeld individuele gesprekken af met partnerrelatiegesprekken, integreert een cliëntgerichte houding met cognitieve technieken, werkt met primaire emoties, toont zich begaan en is een nieuwe heropvoeder die een corrigerende emotionele ervaring aanbiedt daar waar de vroege hechting problematisch was.

De onderzoeker verantwoordt elke stap in het proces, de clinicus kan de opeenvolging van interacties meestal niet navertellen. Het 'one size fits all' van de onderzoekspraktijk is vervangen door het maatwerk in de klinische praktijk. Het idee dat de bevindingen van de onderzoekspraktijk één op één generaliseerbaar zijn naar de klinische praktijk is een misvatting. Veel te vaak wordt over het hoofd gezien dat het hier om structureel verschillende typen praktijken gaat, zonder hiermee de psychotherapeutische praktijk tot een kunst te reduceren. Helaas vergeten veel onderzoekers in de klinische psychologie en psychotherapie dat de academische traditie waarvan ze deel uitmaken - in tegenstelling tot de fysica en wiskunde - pas ruim een eeuw geleden het licht heeft gezien, terwijl Archimedes in 287 voor Christus al het geboortelicht aanschouwde. In de psychologie hebben we nog geen Newton of Einstein meegemaakt. De definitie van het object van onderzoek in de psychotherapie is nog fragmentarisch en onaf. En dan nog: de dagelijkse praktijk van de ingenieurs is van een totaal andere kwaliteit dan die van de fysicus-onderzoeker. De psychotherapeutische praktijk is voortgekomen uit de geneeskundige behandelpraktijk van eind 19e eeuw en heeft sindsdien allerlei vormen gekend waarin veel klinische expertise is opgeslagen in de vorm van gevalsstudies en praktijktheorieën. We zijn er niet aan toe deze klinische rijkdom terzijde te schuiven en ons alleen door de onderzoekspraktijk te laten voeden.

Effectonderzoek is in mijn ogen vooral een consumentenonderzoek, dat niet automatisch zijn wetenschappelijke taak vervult om een bijdrage te leveren aan een belangrijke psychologische theorie in het betreffende domein. Aan de stroom van studies naar het effect van behandelingen lijkt geen einde te komen. Het lijkt wel of aan elke vernieuwing in een psychotherapeutische interventie data vooraf moeten gaan. Vanuit enige distantie beschouwd heeft het iets obsessiefs en ritueels. Vanzelfsprekend werkt dit ook remmend op de ontwikkeling van een psychotherapiemodel en het ontneemt onderzoekers in de psychotherapie energie die besteed zou kunnen worden aan kwesties zoals in dit artikel worden aangestipt. Onderzoek doen naar het proces, de mechanismen die verandering op gang brengen, is in wetenschap- 
pelijk opzicht interessant maar ook beperkt; deze traditie documenteert tenslotte alleen mechanismen in een bestaande praxis en tilt die niet direct naar een hoger plan.

Enkele wetenschappelijke vragen, die naar mijn indruk veel te weinig worden gesteld en voor de huidige empirici wellicht een overdadig filosofisch karakter hebben, zijn de volgende. Aan welke voorwaarden moet een proces van verandering van de intrapsychische architectuur (zoals psychotherapie beoogt) voldoen? Welke ingrediënten kenmerken dit proces en onderscheiden het van een normaal leerproces, gedragstherapie of coaching? Deze vragen abstraheren de bestaande psychotherapeutische praktijk en zijn bedoeld om een theoretisch 'normatief' kader aan te brengen (Derksen, 2007). Alvorens me te wagen aan een beantwoording van de hierboven gestelde vragen, is het noodzakelijk te reflecteren over twee kwesties: het object van de psychologie en daarmee van de psychotherapie, en de ontwikkelingspsychologische optiek.

\section{Kent de psychotherapeutische discipline een object?}

De psychologie ontwikkelde zich in de rijke traditie van de filosofie en haar empirische vorm is niet veel ouder dan een eeuw. Dit is overigens niet geheel correct indien we de bijdragen van David Hume, die leefde en werkte in de 18e eeuw, erbij betrekken, maar sinds het einde van de 19e eeuw is er een meer continu academische benadering in de psychologie gerealiseerd. Op dit moment in onze korte geschiedenis zijn we wellicht (empirisch) sterk genoeg om (filosofisch) te reflecteren op onze fundamenten: hebben we echt een object dat ons helpt onze kennis te organiseren? Indien het antwoord 'ja' luidt, wat is dit object dan precies?

Als gedragswetenschapper kunnen we menselijk gedrag bestuderen. Dit gedrag is het resultaat van een dubbele input: persoonlijkheid en omgeving. Veel gedragswetenschappers gaan door hun werkwijze vooral op historici lijken, ze beschrijven het gedrag in de tijd - op zichzelf zinvol - maar zonder een analyse van het onderliggende patroon te maken. Dat kan in een afzonderlijke wetenschappelijke discipline niet uitsluitend de bedoeling zijn. Psychotherapeutische verandering heeft betrekking op het bewust aanbrengen van een of meerdere wijzigingen in de intrapsychische architectuur. Daarmee wordt niet per se het gedrag veranderd maar wel een van de twee bronnen die de input voor het gedrag leveren. Het zal duidelijk zijn dat ge- 
drag voorspellen praktisch onmogelijk is aangezien de sociale omgeving zelden geheel onder controle kan worden gehouden. ${ }^{1}$

De stelling die ik hier wil verdedigen luidt: het object van de psychotherapie is de intrapsychische architectuur (Derksen, 1983; 2007). De psychologische patronen waaruit deze architectuur bestaat worden gevormd in de individuele geschiedenis beginnend bij de geboorte en krijgen een voorlopige afronding zodra het kind ongeveer vijf jaar is. De mens is vergelijkbaar met een boek: de eerste druk wordt afgerond rond het vijfde levensjaar, waarna herdrukken in het verschiet liggen. Deze intrapsychische architectuur is andersoortig dan die van het brein of die van de cultuur en is ontstaan tussen de biologie en de cultuur in, met gebruikmaking van cultuur en biologie, maar nooit reduceerbaar tot een van beide, ook al willen neurowetenschappers (onder wie veel psychologen) ons dit voortdurend laten geloven (Derksen, 2007). De intrapsychische architectuur is een theoretische constructie, wordt niet empirisch aangetroffen en kan niet descriptief in kaart worden gebracht. Hij kent een relatief autonome positie ten opzichte van de funderende biologie en directe sociale omgeving, er zijn domeinen in geproduceerd met oppervlakte- en diepte-aspecten, met bewuste en onbewuste 'lagen', met sommige delen die behoorlijk goed met behulp van de conditioneringprincipes, met de leer- en cognitieve theorieën kunnen worden begrepen, en andere delen die vaag blijven en waarop de bestaande empirische methodieken daardoor moeilijk grip krijgen. Deze complexiteit maakt het object gemakkelijk tot een strijdtoneel. In een bepaald opzicht beschreef Sigmund Freud (1923) aan het begin van de vorige eeuw de intrapsychische architectuur met concepten uit zijn tijd (id, ego, superego). Iemand als Seymour Epstein (1998) deed dit ook, meer eenvoudig en meer recent (experiental self, rational self). Ik denk dat een theoretische constructie van een object, de intrapsychische architectuur, vruchtbaar kan zijn bij de verdere ontwikkeling van de psychologie in het algemeen en de psychotherapeutische activiteit in het bijzonder. Een theoretisch model is behulpzaam bij (experimenteel) onderzoek en kan zorgen voor de lijm die de overdaad aan data kan ordenen, uitzuiveren, in samenhang kan brengen en vorm kan verlenen. Verderop komen de veronderstelde componenten van de hier bedoelde architectuur aan bod.

\section{Ontwikkelingspsychologische optiek}

Om beter te begrijpen hoe de intrapsychische architectuur kan worden veranderd, moeten we een idee hebben over hoe deze ontstaat en dus een ont-

1 Eén kanttekening wil ik in deze context plaatsen: empirische onderzoekers in de psychologie en in de psychotherapie produceren een enorme hoeveelheid data en doorgaans maar slechts beperkte en kleine theorieën. Elk (onderdeel van) een theorie kan praktisch elke crisis overleven aangezien er altijd weer een onderzoeker op de proppen kan komen met ondersteunende data voor een door de massa al lang vergeten theorie. Het is extreem moeilijk in ons vakgebied definitief vaarwel te zeggen tegen sommige theorieën en op die manier vooruitgang te boeken. 
wikkelingspsychologische optiek hanteren. Vanuit deze optiek is een theorie mogelijk over het ontstaan van deze architectuur en daarmee wordt inzicht verkregen in de verandermogelijkheden. ${ }^{1}$ De kernbegrippen waarmee ik in dit verband probeer zicht te verkrijgen op het proces van het ontstaan van de intrapsychische architectuur zijn: primaire emoties, hechtingsrelatie, cognitieve functies en bewustzijn. De theorie die ik in dit verband ontwikkel, is geplaatst tegen de achtergrond van het empirisch onderzoek zoals dat door Marc Bornstein (2002) in zijn vijfdelig 'Handbook of Parenting' is verzameld, en wordt door mij meer uitgebreid beschreven in mijn boek over narcisme dat eind vorig jaar is gepubliceerd (Derksen, 2007).

In mijn ogen is frustratie een primaire stimulans voor (psychologische) ontwikkeling, stimulatie een secundaire. Met name de cognitieve functies en het bewustzijn vinden hun oorsprong in frustratie, in een tekort, in de afwezigheid van onmiddellijke bevrediging en in de noodzaak om uitstel te leren verdragen. Na de baarmoederlijke condities, waarin een fysiologisch evenwicht bestond, moeten de organen van het menselijk diertje plotseling op eigen benen staan, waardoor het als het ware in een gat valt en wordt geconfronteerd met een tekort. Deze leegte maakt de opbouw van een intrapsychische architectuur noodzakelijk. Niet behoeftebevrediging (lust) maar frustratie stimuleert de opbouw en uitbouw van mentale patronen. Optimale verzorging (bestaande uit voldoende verwenning, frustratie en stimulatie aanbieden) biedt het kind de ruimte voor de opbouw van essentiële intrapsychische patronen en legt zo de basis voor een eigen zelfgevoel (identiteit) en een besef dat de omgeving veilig en betrouwbaar is.

Primaire emoties ontstaan bij de pasgeborene als gevolg van de leegte waarin dit menselijke diertje terechtkomt na de geboorte. De lust-onlustbalans van de kleine botst op de onmiddellijke sociale context. Plezier en pijn verdiepen zich in de loop van het eerste levensjaar door de gebrekkige complementariteit tussen context en biologisch substraat. Lust en onlust bepalen de grondkleur van de emoties die zich vanaf deze basis ontwikkelen. De primaire emoties zijn basaal van aard, beschikbaar voor het heel jonge kind en verschijnen zonder hulp van cognities (Ekman, 1992). Emoties wellen op zoals water uit een bron, geholpen of tegengewerkt door de onmiddellijke textuur van de sociale omgeving. In tegenstelling tot emoties worden gevoelens gekenmerkt doordat er cognitieve functies (waarnemingen, geheugenmateriaal, taal, redeneervermogen, kortom alles wat met een brede intelligentietest wordt gemeten) in meewerken, gevoelens zijn meer uniek en individueel van aard. Emoties vormen de ruwe ondergrond voor gevoelens. Indien bij een volwassene de emoties overheersen betekent dit dat de cognities hierop onvoldoende vat hebben kunnen krijgen. In allerlei typen menselijk gedrag, en meer in het bijzonder bij mensen met een ernstige persoonlijk-

1 Trouwens, een psychotherapeut die nooit kinderen en jongeren ziet of helpt en zich uitsluitend beperkt tot volwassenen, mist de ondergrond en achtergrond van diens eigen vakgebied en komt daarin overeen met een verkoper van auto's die geen idee heeft hoe de motor werkt. Een van de manieren van psychotherapeuten om een beetje blind te blijven is geen studie te doen naar ontwikkelingspsychologische processen en ontwikkelingspsychopathologie. 
heidsstoornis, kun je dit terugzien; op het moment dat mensen door sterke emoties worden overmand, is de rationaliteit zoek. Anders - een tikje somberder - uitgedrukt: de emoties stellen de reikwijdte vast die op een dergelijk moment aan de invloed van het verstand wordt toebedeeld. Cognities en bewustzijn worden tijdens deze doorbaak opzijgeschoven zoals het gordijn aan het begin van een toneelvoorstelling. Tegenwoordig worden zes basale, primaire, ook wel universeel genoemde emoties onderscheiden: angst, geluk, verdriet, boosheid, verbazing en walging. Neurobiologisch gezien zijn er argumenten voor twee afzonderlijke circuits in de hersenen (de amygdala, het oudere hersendeel en de cortex, recenter in de evolutie ontwikkeld en drager van cognitieve functies). De emoties staan in dienst van de continuïteit van het leven en zijn nog steeds tamelijk functioneel voor een volwassene in de krottenwijken van India, maar veel minder voor een zakenman in de City van Londen.

In de affectieve relatie van het kind met de moeder en/of de vader reageert de ouder idealiter rustig en betrouwbaar op expressies van angst, boosheid en walging door het kind (Winnicot, 1971). Er is geen betere voorspeller voor de transitie van emoties naar gevoelens en voor de cognitieve bloei bij een kind dan de omgang met een responsieve moeder (vader of verzorger) met wie een veilige hechting is ontstaan. De hechtingsrelatie met de verzorger krijgt vorm in het eerste levensjaar. Ze voorziet het kind idealiter van een ervaring van basale veiligheid en helpt bij het reguleren van de primaire emoties (Fonagy, Gergely, Jursit \& Target, 2004). De hechtingspersoon opent de weg voor de cognitieve functies en vergemakkelijkt de invasie van de cognitie in de toppen van de emotie. Doordat de verzorger zelf niet angstig of boos wordt, kan het kind zich geleidelijk aan identificeren met deze houding en deze op zichzelf gaan toepassen. In de context van deze ontwikkeling wordt emotieregulatie mogelijk maar ook impulscontrole en het monitoren van het zelf. De wijze waarop de hechtingsfiguur omgaat met de emoties van het kind, draagt in belangrijke mate bij aan het latere emotiemanagement van de volwassene.

Hechtingsrelaties helpen emoties reguleren, helpen afweer opbouwen en dienen het principe van uitbreiding van de soort en overleving. De zich ontwikkelende egofuncties hebben onder meer tot taak om te voorkomen dat extreem positieve en extreem negatieve (niet gemengde en gefuseerde) emoties uit de hand lopen, en het gedrag en de beleving overmatig bepalen. De egofuncties, gestimuleerd in de hechtingsrelatie, halen de schotten tussen deze emoties weg zodat menging (en dus verdunning) optreedt en ambivalenties kunnen worden verdragen. Bij gebrekkige egofuncties, zoals we die kennen bij mensen met psychotische symptomen en met een ernstige persoonlijkheidsstoornis, ontbreekt het vermogen om ambivalenties te verdragen, waardoor mensen bijvoorbeeld niet tegelijkertijd kunnen voelen dat ze om iemand geven en zich aan diegene ergeren. Liefde en haat lopen uit de hand, worden sterk overdreven en de ander wordt óf als helemaal goed óf als helemaal slecht ervaren met alle gevolgen van dien voor de relatie met die persoon. 
Op de kleuterleeftijd begint het bewustzijn warm te lopen, voorafgegaan door de motorische activiteit, met de emoties als brandstof (Damasio, 200o). Bewegingen leiden tot emoties, emoties lokken het bewustzijn uit. Het kind begint te snappen - als gevolg van de opbloei van de cognitieve functies dat zowel de verzorger als hijzelf ervaringen en belevingen hebben die tot gedrag leiden. Kinderen kunnen zo gedrag van anderen op den duur als betekenisvol begrijpen. Het kind snapt, samen met de toenemende actieve verwerving van de taal, dat vader opgewonden is want hij staat op de uitkijk naar de ijscoman met malaga-ijs; het vermogen tot mentaliseren komt op gang. De cognities die zich in deze context ontwikkelen, zijn noodzakelijk voor de opbouw van het zelf en vormen mede dit zelf. Het fragmentarische bewustzijn dat hier ontstaat, heeft betrekking op het zelf. Het begripsvermogen dat zich nu ontwikkelt, schiet te hulp bij het managen van emoties. De inwerking van cognities op emoties roomt de intensiteit af en bewerkt ze tot gevoelens, zonder dat alle emoties in het snoeiproces verloren gaan. Gevoelens worden eveneens uitgelokt door emoties van het kind, door waarnemingen van lichamelijke processen, door motorische activiteit, door percepties van objecten in de buitenwereld en door de beginnende cognitieve processen van het kind zelf. Alles gebeurt op en rond een eilandje dat we het 'zelf' noemen.

De posities in deze architectuur komen niet tot stand zonder dat er energie in wordt geïnvesteerd. Bij de zuigeling zit de dominante beleving vastgekoppeld aan het lichaam. Dit lichaam is in aanvang een onbestuurbaar schip, het schiet alle kanten op en het lukt de kleine niet hiermee doelgericht te werken. De beleving van het lichaam is verbrokkeld. Pijn in de buik wordt onderin het lichaampje gevoeld, het stoten van het handje doet zeer, het zuigen met de lippen is lekker. Geleidelijk aan lijkt de bedrading de motoriek aan te sturen; het kind krijgt controle over zijn bewegingen en neemt zijn lichaam als een geheel waar, waardoor het zelf een fundament verkrijgt. Het beeld van het gehele lichaam in de spiegel, dat bestuurbaar aan het worden is, heeft de functie van een steiger, behulpzaam bij de opbouwwerkzaamheden van het zelf en de identiteit. Het bewustzijn breekt in deze periode pas goed door, zoals de lucht kan openbreken na een stevige regenbui. Eerder was het bewustzijn fragmentarisch, gekoppeld aan de van binnenuit opkomende en uitgelokte emoties, maar nog geen doorlopend filmpje in het brein. Door de vergrendeling van dit bewustzijn aan het zelf krijgt de film continuïteit. Deze continuïteit ontstaat bij het opentrekken van de lucht, maar het kost nog maanden voordat ze het niveau verwerft van wat we het autobiografische zelf noemen.

Het zelf is vergelijkbaar met een tweetrapsraket; de eerste stuwkracht komt vanuit de hechtingsfiguur en de tweede vanuit de narcistische ervaringen. De eerste motor brengt de raket buiten de dampkring en de tweede brengt het zelf buiten de aantrekkingskracht van moeder aarde. Het zelf verkrijgt een eerste schets nadat de ander is ervaren, en krijgt vorm als een uitbreiding van deze ervaring van de ander. In de ogen van de hechtingsfiguur, heel vaak de moeder, ervaart het kind dat het bestaat. De eerste verflaag, de grondverf van het zelf, wordt aangebracht door de ander. Tijdens de 
werking van de tweede trap wordt, geholpen door een blik in de spiegel en de identificatie met een totaalbeeld, het zelf versterkt door narcistische belevingen. De autonomie krijgt verder gestalte; de ander wordt nu ervaren als een verlengstuk van het zelf (Derksen, 2007).

De eerste druk van de intrapsychische architectuur omvat de emotieregulatie, het bewustzijn van een zelf en het bewustzijn van de lichamelijke conditie en van de buitenwereld. In dit bewustzijn zijn de cognitieve functies werkzaam die behulpzaam zijn bij het taalgebruik, de denkprocessen, de afweer en de coping. De hechtingsprocessen hebben interne werkmodellen opgeleverd die de regie voeren over hoe de persoon met anderen omgaat. Er is vanuit de hechtingsrelatie een superego en vanuit de narcistisch ervaringen een ego-ideaal meegeleverd. De verhouding tussen het zelf en de ander komt in gedrag steeds opnieuw uit de startblokken.

Deze architectuur kan gedurende het leven worden herdrukt. Tijdens de adolescentie, een levensfase tussen ongeveer 10 en 20 jaar, dus inclusief de puberteit, introduceert de mogelijkheid van een herdruk zichzelf. De drukpersen komen samen met de lichamelijke rijping op stoom. Deze lichamelijke rijping draagt ertoe bij dat de oude druk beetje bij beetje uiteen begint te vallen en er vanwege slijtage een herdruk noodzakelijk wordt. Separatie is de primaire taak van de adolescent. Het toneel wordt gevormd door de vroegkinderlijke hechtingsrelaties en de erop volgende narcistische ervaringen. De vroegkinderlijke - symbiotische - inhoud wordt tijdens de adolescentie afgezworen met behulp van energie uit de narcistische ervaringen. De adolescent ontdoet zich van de symbiotische relatie met moeder of verzorger, maar de behoefte hieraan kan groter blijken te zijn dan vanuit de narcistische beleving werd verwacht, waardoor er een leegte ontstaat die niet meteen door een andere (intieme) relatie wordt ingevuld. Relaties met leeftijdsgenoten zorgen voor enige inhoud maar deze is kwetsbaar aangezien de meeste jongeren tijdens de vroege en middenadolescentie niet uitblinken in empathie en rekening houden met elkaar. Deze adolescentie biedt een tweede kans voor kinderen bij wie de gehechtheid heeft geleid tot sterke geïnternaliseerde ouderobjecten. Het is als de revanche van het voetbalelftal dat uitspelend nipt verloor en nu zelfverzekerder dan ooit van plan is de thuiswedstrijd te winnen. De ouders of verzorgers hebben de plaats van het egoideaal en het geweten ingenomen. Deze richtingsaanwijzers zijn aan vervanging toe, ze moeten opnieuw worden geijkt, en krijgen idealiter in het leven van de jongvolwassene op een persoonlijke wijze vorm. De ruimte die op het niveau van het ego-ideaal en het geweten schoon wordt geveegd, vult de adolescent in met de nieuw verworven capaciteit tot abstract denken en filosoferen. Afstand nemen van de geïnternaliseerde ouderobjecten veronderstelt een streven naar autonomie dat aanvankelijk dobbert op agressie en wordt onderhouden door het abstracte denken. De agressie betreft in de kern de afhankelijkheid van interne objecten maar wordt doorgaans niet binnen (intrapsychisch) uitgevochten, maar buiten (op straat) en dus met de ouders. Afwezigheid van enige agressie of verzet kan betekenen dat het boek niet wordt herdrukt en dat een stap in het individualisatieproces wordt overgeslagen. 
Met het opnieuw in het spel komen van de hechtingsrelaties krijgt de emotieregulatie een vanzelfsprekende hoofdrol op het toneel. Elk actueel gevoel, vaak het gevolg van interacties met anderen, loopt de kans op versterking vanuit de vroegkinderlijke emoties. Dit betekent dat de adolescent heel sterke gevoelens ten opzichte van personen en dingen ontwikkelt. Gegeven de sterke beleving kan de vroege adolescent zich niet indenken dat hij ooit iets anders zal voelen voor iets of iemand dan nu het geval is. Indien emoties (dus zonder cognitieve invloed) vat hebben op strevingen, motieven en opvattingen, worden deze verabsoluteerd en zijn in hun bloeitijd niet beïnvloedbaar. In de loop van de adolescentie breekt geleidelijk het besef door dat omkeerbaarheid wel degelijk mogelijk is, maar er zijn ook volwassenen die in dit opzicht adolescent zijn gebleven.

Welke componenten kunnen we onderscheiden in de (volwassenen) intrapsychische architectuur? De componenten vallen ten dele samen met de hier beschreven mechanismen in de opbouw ervan. De gevoelens die het product zijn van de emotieregulatie; de hieronder liggende restanten van de primaire emoties; de cognitieve functies; het bewustzijn dat nauw verbonden is met cognities en gevoelens. Kern van dit bewustzijn is het zelf: beelden en gevoelens, bewust en minder bewust, over de eigen persoon. Het evenwicht in de intrapsychische architectuur wordt vormgegeven door een typische verhouding tussen gerichtheid op het zelf en gerichtheid op de ander. De gerichtheid op de ander komt voort uit de hechtingservaringen, de gerichtheid op het zelf uit de narcistische belevingen. In dit verband onderscheiden we mensen op de dimensie activiteit versus passiviteit, we noemen dit vaak coping (Millon, 1996). Tijdens de ontwikkeling van het ego-ideaal wordt de gerichtheid op het zelf minder en beginnen kinderen zich meer op de ander te richten, waarbij het geweten verder tot ontwikkeling komt, nadat hiervoor de grondslag werd gelegd tijdens het proces van hechting in het eerste levensjaar. Al deze patronen zijn vaak 'slapend' aanwezig en worden geactiveerd in het menselijke gedrag dat steeds in een sociale en fysieke omgeving plaatsvindt en daarin dialectisch is geïntegreerd. Gedrag is steeds de resultante van de dubbele input, ook al is het onderscheid tussen omgeving en architectuur feitelijk alleen theoretisch.

\section{Psychotherapie in actie}

De openleggende benaderingen, waarin getracht wordt verbetering te realiseren door de cliënt diens binnenwereld te laten verkennen, grijpen aan op de intrapsychische architectuur. Trainingen en vormen van begeleiding grijpen aan op het gedrag en dus op het product van twee bronnen: de intrapsychische architectuur plus de directe sociale omgeving. Therapeutische behandeling door middel van gedragsinstructies in combinatie met blootstelling, training en cognitieve ondersteuning met nieuwe schema's is vaak succesvol. Gedragstraining helpt mensen keuzemogelijkheden in het gedrag te ontdekken en deze via blootstelling te oefenen. Dit verloopt hoofdzakelijk via de weg van de leer-en conditioneringsprocessen. Veel ontdekkende psy- 
chotherapieën, maar ook veel sociale-vaardigheidstherapieën helpen mensen hun zelfgevoel te versterken, helpen hen meer voor zichzelf te kiezen, hun grenzen beter te stellen, hun eigen keuzes te ontwikkelen, hun weggedrukte gevoelens beter onder ogen te zien en eventueel tot uiting te brengen, hun autonomie te versterken. Ontdekkende of openleggende psychotherapie, binnen uiteenlopende kaders als cliëntgerichte psychotherapie, cognitieve psychotherapie, schematherapie, interpersoonlijke psychotherapie, psychoanalytische of psychodynamische psychotherapie, is vaak gericht op het loskomen van de geïnternaliseerde ouderbeelden, het doorwerken van weggedrukte conflicten in de vroege objectrelaties en dus op het verminderen van de beperkende invloed die de gehechtheid uitoefent op de emotieregulatie. Dit kan op zijn plaats zijn als er bij het transformeren van emoties naar gevoelens emotie verloren is gegaan en ongereguleerd is gebleven, waardoor deze niet als psychische energie beschikbaar komt en terugkeert in de vorm van symptomen.

Mensen die relatief meer door de hechting dan door de narcistische ervaringen zijn gevormd en die vastlopen in een overheersende op het zelf gerichte maatschappelijke context, krijgen van de psychotherapeuten hulp om narcistischer te worden en daarmee wordt hun aanpassing aan het dominante cultuurpatroon versoepeld. De gehechtheid heeft hier vaak tot onderdrukking van boosheid en agressie geleid en heeft daarmee de mogelijkheid om deze emotie te transformeren naar autonomie en zelfdirectie verminderd. Op individueel niveau wordt dit veranderingsproces gevoeld als een emancipatieproces en op cultureel niveau is het een verbeterde aanpassing aan de actuele context.

In het kader van de theorie die hier wordt ontwikkeld, kunnen we over de mechanismen in de werkzaamheid van psychotherapeutische interventies preciezer zijn. Essentieel voor psychotherapie is dat deze aangrijpt op een van de drukken van de intrapsychische architectuur. Soms kan en moet dit op de eerste druk zijn die in de kindertijd is vervaardigd. De methodiek die hierop tot nu toe het meest systematisch en expliciet was gericht is de psychoanalytische behandeling. De bedoeling van elke klassieke bankanalyse of hoogfrequente psychoanalytische psychotherapie is het laten ontstaan van een overdrachtneurose (Langs, 1973). Hiermee wordt bedoeld dat middels een langdurig, regressief proces de vroegkinderlijke reactie- en belevingswijze via de overdracht op de persoon van de psychoanalyticus boven komt drijven en dat de klachten in deze relatie benoemd kunnen worden: hechting, primaire emotie, cognitieve functies en bewustzijn doen het werk in het hier-en-nu-proces van de overdracht. Door de typische wijze van werken, met vrije invallen en een passieve analyticus, komt dit proces traag op gang en tegenwoordig is er een heel arsenaal aan technieken beschikbaar voor een veel actievere psychotherapeut waardoor ditzelfde proces veel sneller en zelfs dieper op gang kan komen. Allerhande meer alternatieve therapieën die lichaamsgericht werken of de patiënten met regressie opwekkende technieken bejegenen, zijn eveneens gericht op heel vroege patronen, maar hier wordt doorgaans zonder goede theorie gewerkt en wordt de aanvangsdiagnostiek verwaarloosd. De cognities en het bewustzijn worden vaak onderbe- 
licht en de emoties overschat. In een leerproces - dominant bij bijvoorbeeld internettherapie - daarentegen domineren de cognities en zijn de primaire emoties afwezig.

Een herdruk, als gevolg van psychotherapie, houdt in dat er een accentverschuiving in de architectuur wordt aangebracht. Dit kan betekenen dat weggedrukte primaire emoties alsnog worden beleefd en worden getransformeerd tot gevoelens. Met het bijbehorende cognitieve begrip en het zich verruimende bewustzijn levert dit een 'grotere' intrapsychische ruimte op, het mentaliseren ontwikkelt zich, de psychologische flexibiliteit neemt toe en starheid als gevolg van geblokkeerde emoties vermindert. Dit leidt tevens tot herschikking van de verhouding tussen wensen en verlangens enerzijds en de superego- en ego-ideaalposities anderzijds. Het realiseren van een herdruk lukt, volgens de theorie die hier wordt ontwikkeld, alleen onder condities die vergelijkbaar zijn met die waaronder de eerste druk ontstond: hevige, primaire emoties die in de context van een hechtingsrelatie worden gekanaliseerd met behulp van cognitieve functies. Voorts moet dit proces leiden tot een verruiming van het bewustzijn.

Voor psychotherapie betekent dit uitgangspunt dat structurele verandering van de intrapsychische architectuur mogelijk is als dieperliggende, primaire emoties en ermee samenhangende conflicten worden geactiveerd, in het hier en nu gevoeld (blootstelling) en beleefd (tot expressie gebracht) en als ze met behulp van taal een verruimende invloed uitoefenen op het bewustzijn. Cruciaal op deze momenten in het behandelproces zijn vier ingrediënten: de (gehechtheids)relatie van de patiënt tot de therapeut; de activering van primaire emoties; het verruimen van het bewustzijn met nieuwe cognities. De psychotherapeut biedt idealiter een corrigerende, emotionele ervaring aan door diens opstelling en hantering van de relatie. Zonder expressie van (primaire) emoties in het hier en nu en hernieuwde koppeling aan cognities, en dus bewuste beleving, is de kans op herstructurering van de intrapsychische ruimte klein. Met activering van die emoties en een vernieuwde en verbeterde emotieregulatie, geholpen door nieuwe cognities, met behulp van een nieuw verworven gehechtheid aan de psychotherapeut, is de kans op structurele verandering groot. Met de regulering van emoties ontstaan in dit proces (alsnog) meer (verfijnde) gevoelens.

In veel gevallen bestaat er geen directe noodzaak de eerste druk te beïnvloeden. Er zijn gedeeltelijke herdrukken geweest ten gevolge van emotionerende ervaringen; een bewerking van deze ervaringen met toegang tot het bewustzijn kan voldoende zijn voor psychotherapeutische verandering. Hiervoor geldt eveneens dat de emoties die toen deel uitmaakten van deze ervaringen in het hier en nu moeten terugkeren en soms ook voor het eerst verschijnen. Op de achtergrond speelt de hechting mee zoals het decor in een toneelspel. Zonder dit decor wordt de boodschap niet adequaat in het bewustzijn gebracht. Zonder enige hechting is psychotherapeutische beïnvloeding van de intrapsychische architectuur, en dus ook verbreding van het bewustzijn, niet mogelijk. Vanzelfsprekend kunnen allerlei vormen van psychologische behandeling en begeleiding effectief zijn door het leerproces dat 
ermee op gang wordt gebracht. Dit is echter iets anders dan een rechtstreekse en structurele beïnvloeding van de intrapsychische patronen.

Maar het bovenstaande betekent niet dat iedereen die hevig emotioneel wordt een belangrijke verandering doormaakt in de patronen die gedrag en beleven funderen. Veel mensen drukken op allerlei momenten sterke emoties uit maar die worden niet binnen de context van een (surrogaat) hechtingsrelatie gereguleerd. Technisch uitgedrukt: de ontwikkelde afweer schuift tijdelijk opzij ten gunste van de primitieve defensie. Met name splijting zorgt er dan voor dat een zeurend probleem (schijnbaar) wordt opgelost door bijvoorbeeld te 'besluiten' (met behulp van splijting) degene die ervoor verantwoordelijk wordt gehouden nooit meer te gaan zien. Alleen expressie, dat wil zeggen het uitleven van emoties, verandert niets aan het bewustzijn van de persoon in kwestie, tenzij er een sociale context is die dit bewustzijn met behulp van de juiste cognities beïnvloedt.

In een leerproces spelen cognities de eerste viool en hiermee worden fragmenten van het bewustzijn als het ware meegetrokken. Als de primaire emoties in het hier en nu buitenspel blijven, is de structurele invloed van het proces op de intrapsychische architectuur echter beperkt. Dit wijst op de inherente beperking van cognitieve therapie indien er in dit proces geen primaire emoties worden geactiveerd en opnieuw gereguleerd in een relatie met een hechtingsfiguur. Cognitieve gedragstherapie is zich, door een technische ontwikkeling, wel toenemend gaan richten op de vroege drukken van de intrapsychische architectuur maar legt vooral een accent op cognities en mist, bij een technisch beperkte toepassing, de kans om de primaire emoties te beïnvloeden. Bij een therapeutische strategie die hoofdzakelijk op cognities is gericht, zoals geldt voor cognitieve therapie, ligt het voor de hand dat het in het hier en nu actualiseren van primaire emoties tekortschiet en daarmee de effectiviteit niet optimaal is. In het werken met cognities wordt het bewustzijn ook geactiveerd, maar dit bewustzijn ontwikkelde zich in de vroege kindertijd in belangrijke mate ook door de combinatie van voelen en denken. Zonder een meer of minder sterk gevoelsproces is de intensiteit voor het bewustzijn onvoldoende om voor doorbraken te zorgen. Bij schemagerichte therapie wordt getracht de cognitieve therapie aan te vullen door zich meer te concentreren op de emoties die gepaard gaan met de dieperliggende schema's. De kans op structurele verandering van de psychische patronen is dan vanzelfsprekend groter.

In het psychotherapieproces kunnen de vier ingrediënten ook nog in een bepaalde volgorde worden geïntroduceerd. Bij cliënten met neurotische problematiek en een veilige hechting kan vrij snel gewerkt worden aan het actualiseren van primaire emoties door het bewerken van de afweer. Dit gebeurt in de diverse varianten van psychodynamische psychotherapie zoals die in de traditie van Davanloo (2000) zijn uitgewerkt. De hechting komt tamelijk gemakkelijk op gang. Juist ook bij het oproepen van authentieke emoties en het laten beleven van die emoties in het hier en nu, worden vaak nieuwe cognities opgeroepen en verruimt het bewustzijn zich. Indien dit proces in aanvang, bij de eerste druk van de architectuur, al weinig verstoord was kan het nu gemakkelijk worden beïnvloed. Bij neurotici met een onveilige of ambi- 
valente gehechtheid moet er aan het begin meer werk worden gemaakt van de hechting aan de psychotherapeut. Dit proces gaat dus langzamer. Pas geleidelijk aan kan aan het activeren van primaire emoties worden toegekomen. Bij patiënten die op een borderline-niveau functioneren, met vaak een gedesoriënteerde of gedesorganiseerde gehechtheid, vereist deze gehechtheid veel aandacht en tijd, en staat vervolgens het bewerken van de cognitieve patronen als eerste op de behandelagenda. Hiermee wordt als het ware een buffer opgebouwd om de primaire emoties te lijf te gaan. Bij patiënten die een psychotische kwetsbaarheid kennen, is het oproepen van primaire emoties niet geïndiceerd, aangezien hun egosterkte hiervoor doorgaans te gering is en de doorbraak van een primaire emotie kan leiden tot een psychose. In de klinische praktijk zien we dit vaak bij doorbraken van heftige gevoelens van agressie of verliefdheid. Dit kan het beste worden vermeden. Een diepgaande hechting roept bij deze kwetsbare mensen ook gemakkelijk primaire emoties op en dan krijgen we dezelfde psychotische verstoring. Het verdient dan de voorkeur aan cognitieve patronen en cognitieve herstructurering te werken en daarbij te vermijden primaire emoties op te roepen. Het bewustzijn kan worden verruimd op een wijze zoals we dat kennen bij een leerproces.

De wetenschappelijke opgave bestaat er in dit verband uit de vier ingrediënten en de nu nog vaag beschreven componenten van de architectuur vollediger te analyseren. De cognitieve functies hebben in de onderzoekspraktijk tot nu toe de meeste aandacht gehad. Met name de rol van het bewustzijn moet aanzienlijk verder worden verhelderd. Het bewustzijn staat hoog op de agenda van neurobiologisch onderzoek, maar een analyse van de psychologische mechanismen in dit bewustzijn blijft achterwege.

\section{Een casus}

Hier volgt tot slot een casus om het bovenstaande aan te illustreren. Een 37-jarige vrouw heeft een probleem in haar werk. Ze heeft voor haar gevoel voor het eerst, na zeven jaar werkzaam te zijn bij het bedrijf, te horen gekregen dat haar functioneren niet door de beugel kan. Haar wordt verweten dat ze herhaaldelijk agressieve uitbarstingen heeft en dan mensen die aan haar rapporteren op een onheuse wijze bejegent. Het komt voor dat ze het kantoor waar deze medewerkers bezig zijn binnenstormt, hun vermeende fouten of vergissingen declameert en stampvoetend vertrekt, allen in verbazing achterlatend. Mensen voelen zich vaak op allerlei manieren door haar geschoffeerd. De leidinggevende van deze 37-jarige vrouw krijgt klachten over haar, maar de klagers willen anoniem blijven. Ze heeft nu te horen gekregen dat het vijf voor twaalf is: of ze roept hulp in en verbetert haar gedrag of ze krijgt een outplacementtraject. Mevrouw voelt zich gedwongen hulp in te roepen en bagatelliseert de voorvallen op haar werk. Uit de onderzoeksgesprekken komt deze alleenstaande, academisch opgeleide dame naar voren als iemand die zeer veel verantwoordelijkheid neemt in haar werk, 's ochtends als eerste aanwezig is en 's avonds het 
licht uit doet, moeite heeft met delegeren ('nu weet ik zeker dat het goed gaat') en hoge eisen stelt aan zichzelf en aan anderen. Haar werklast heeft ze door de eigen houding vergroot, de stress is toegenomen in de context van een reorganisatie en geleidelijk aan is ze de laatste jaren steeds gespannener geworden onder haar werk.

In een psychotherapeutisch traject worden de interventies primair gericht op haar intrapsychische architectuur: haar superego is overdadig streng en bestraffend, en dieperliggend gaat dit gepaard met sadistische fantasieën waaronder ze masochistisch lijdt en geniet. Ze ontzegt zich, zo blijkt, in dit proces elk genot, is onvermogend om passief te zijn en is dwangmatig altijd bezig. Ze blijkt in haar hechtingsrelatie en in de hiermee samenhangende identificatie met haar vader sterke erotische gevoelens af te weren. Het ontdekken, beleven, bewust worden en bewerken van deze afgeweerde primaire emoties, in een hechtingsrelatie tot de psychotherapeut, leidt tot versoepeling van haar superego en daarmee samenhangend wordt ze ook voor anderen een plezieriger persoon.

In een gedragstherapeutische aanpak is het probleemgedrag het aanknopingspunt. Haar woedeaanvallen blijken te ontstaan zodra ze zittend achter haar bureau haar e-mails leest en ontdekt hoeveel taalfouten hierin staan en hoe onvolledig de antwoorden op haar vragen zijn. Dan schiet ze als door de bliksem getroffen overeind en verandert in een gifpijl voor de desbetreffende persoon. Met impulscontrole-technieken wordt haar volgens een protocol geleerd zichzelf in de werksituatie te beheersen, voorts krijgt ze stressmanagement-training en hulp bij timemanagement. De cognitief-gedragstherapeut kan zich in de hiervoor genoemde aanpak vinden, maar besteedt ook aandacht aan haar cognities en helpt haar bij het versoepelen van de perfectionistische ideeën. De schemagerichte psychotherapeut gaat dieper in op de kenmerkende patronen in haar cognitieve functies, het bijbehorende bewustzijn en de gevoelens. In de hulp die een coach kan bieden staat haar gedrag op het werk centraal, hieromtrent krijgt ze tips en adviezen. De coach blijft op afstand van haar privéleven en van het ontstaan van de haar kenmerkende gedragingen.

Ook de behandelaars die het gedrag als aanknopingspunt kiezen zullen beweren dat hun werk tot structurele wijzigingen leidt: het gedrag verandert en dit leidt tot nieuwe interacties die dermate belonend zijn dat het zelfgevoel verbetert, etc. Ook in deze gevallen ben ik van mening dat voor die structurele veranderingen dezelfde ingrediënten noodzakelijk zijn. De relatie tot de therapeut als een hechtingspersoon blijft cruciaal. Primaire emoties moeten worden opgeroepen. Cognitieve functies moeten worden ingeschakeld en moeten mede met behulp van een verbreding van het bewustzijn leiden tot een nieuwe regulering van deze emoties. Dat hoeft niet allemaal in de zitting plaats te vinden. Het is denkbaar dat in een oefenprogramma de patiënt in een fantasmatische relatie tot de behandelaar (die op dat moment niet aanwezig is) veel voelt, ervaart en meemaakt. 
Het aangrijpingspunt is dus niet alles bepalend, de noodzakelijke ingrediënten zijn dat wel.

\section{Besluit}

Het voorafgaande is te lezen als een pleidooi om het bestaande psychotherapie-onderzoek niet alleen op gepaste afstand te houden van de complexe psychotherapeutische praktijk, maar ook aan te vullen met theoretische modellen die de intrapsychische architectuur documenteren en het mogelijk maken om psychotherapeutische verandering van dit object theoretisch en ook normatief te beschrijven. In dit artikel werd hieraan een bijdrage geleverd vanuit een ontwikkelingspsychologisch perspectief.

\section{Literatuur}

Blanton, H., \& Jaccard, J. (2006). Arbitrary metrics in psychology. American Psychologist, 61, 27-41.

Bornstein, M. (2002). Handbook of Parenting Vol I-V. New Jersey: Lawrence Erlbaum Associates Publishers.

Damasio, A. (200o). The feeling of what happens, body emotion and the making of consciousness. London: Vintage.

Davanloo, H. (200o). Intensive Short-term Dynamic Psychotherapy, Selected Papers. New York: John Wiley.

Derksen, J. (1983). Psychotherapieën in het geding. Baarn: Nelissen.

Derksen, J. (2007). Zijn we wel narcistisch genoeg? Over het ontstaan van onze lentecultuur als gevolg van gewijzigde vroegkinderlijke condities. Nijmegen PEN Tests Publisher.

Ekman, P. (1992). An argument for basic emotions. Cognition and Emotion, 6, 3-4, 169-20o.

Epstein, S. (1998). Constructive thinking: The key to emotional intelligence. Westport, CT: Greenwood Publishing.

Fonagy, P., Gergely, G., Jursit, E., \& Target. M. (2004). Affect Regulation, Mentalization, and the Development of the Self. London: Karnac.

Freud, S. (1923). Das Ich und das Es. Frankfurt am Main: Fischerverlag, Studienausgabe Bd. III, 1975 .

Kazdin, A. (2008). Evidence-Based Treatment and Practice. American Psychologist, 63, 3, 146-159. Lacan, J. (1971). Écrits II. Paris: Éditions du Seil, 1971.

Langs, R. (1973). The Technique of Psychoanalytic Psychotherapy. New York: Jason Aronson. Millon, Th. (1996). Disorders of Personality DSM-IV and beyond. New York: John Wiley \& Sons.

Millon, Th., Boice, A., \& Sinsabaugh, K. (2008). Realting personalized assessment to personalized psychotherapy. In: Th. Millon, \& C. Bloom. The Millon Inventories. New York: The Guilford Press, 15-45.

Snyder, C., \& Ingram, R. Eds. (200o). Handbook of Psychological Change. New York. John Wiley \& Sons.

Winnicot, D. (1971). Playing and Reality. London: Tavistock Publications. 